\title{
Legal Protection to Limited Company that Does not Do Adjustments to Business Licensing and Online Single Submission After the Issue of Government Regulation Number 24 of 2018
}

DOI: https://doi.org/10.47175/rissj.v2i2.221

\author{
| Muthia Susan Fadillah Bulolo ${ }^{1, *} \mid$ Ramlan $^{2}$ | \\ ${ }^{1}$ Student of Master of Notarial \\ Program, Universitas \\ Muhammadiyah Sumatera \\ Utara, Indonesia \\ ${ }^{2}$ Lecturer of Law Faculty, \\ Universitas Muhammadiyah \\ Sumatera Utara, Indonesia \\ "muthiasusanfadillah@yahoo.com

\begin{abstract}
Licensing adjustments related to the operational legality of Limited Company that is established before the issued of Government Regulation Number 24 of 2018. For Limited Company (PT) that is established before the issued of Government Regulation Number 24 of 2018 and do not have Master Number Attempted (NIB), but already have Business License Indonesia (SIUP), legally the company can still carry out operational activities. business as usual legally (but imperfectly). This research uses a type of normative research, using a statutory approach and a research approach to the level of vertical synchronization. This research is descriptive analysis, and the results of the study use qualitative analysis. The results show that for legal protection for business actors by adjusting the PT's license to OSS so as not to lose money in order to establish relationships with third parties. Because there are no strict sanctions for business actors who do not make adjustments to PT to OSS.

KEYWORDS

protection; business licensing; OSS; PT
\end{abstract}

\section{INTRODUCTION}

In a business context, a form of business legality is ownership of a business license. The existence of ownership of a business license can certainly reduce the worries of business actors in terms of licensing. Then in obtaining company legality, the company must carry out certain procedures based on applicable regulations as stipulated by the Government. In the end, business legality will certainly provide benefits for companies in the field of licensing and operating their business activities. Then related to a company in the form of a company, Limited Liability Company (PT) is a form of company that is established as a legal entity by law (Indra Jaya \& Sudantra, 2020: 494).

The establishment of a Limited Liability Company Legal Entity by the founders must be stated "in writing" in the form of a deed, namely in the form of a Notarial Deed (Notariele Akte, Notarial Deed), it may not be in the form of an underhandse deed, private instrument. The requirement for the Deed of Establishment must be in the form of a Notary Deed, not only as a probationis causa. It means that the Notary Deed does not only function as "evidence" of the agreement for the establishment of PT. This is stated in Article 7 paragraph (1) of Law Number 40 of 2007 concerning Limited Liability Companies (UUPT) which reads: "The company is established by 2 (two) or more people with a Notary deed made in Indonesian".

Based on this article, the establishment of a PT must be based on a Notary Deed made in Indonesian. The deed of incorporation contains the articles of association and other information relating to the establishment of the PT, at the same time it has the character 
and functions as a solemnitatis causa, that is, if it is not made in the Notary Deed, the deed of establishment of the Company does not meet the requirements, so that it cannot be given "approval" by the Government, in this case the Minister. Law and Human Rights (Harahap, 2011: 168-169). In drawing up a deed of establishment before a Notary Public, the founders can appear before the Notary on their own or can be represented by another person based on a power of attorney.

In the framework of the establishment of a PT, the mechanism does not stop at the creation of a deed of establishment which is written only in an authentic deed, Article 7 paragraph (4) of the Company Law stipulates that the PT has the status of a legal entity. The article reads: "The Company obtains legal entity status on the date of the issuance of the Ministerial Decree concerning the legalization of the Company's legal entity". Then proceed to the Legal Entity of the Limited Liability Company issued in the form of a Ministerial Decree called the Decree of Legal Entity of the Company. Article 9 paragraph (1) of the Company Law determines that in order to obtain this Ministerial decision, the founders together submit an application through information technology services. In the event that the founder does not submit the application himself, according to Article 9 paragraph (3) of the Company Law the founder can only authorize a Notary (Harahap, 2011: 173).

PT that has received approval from the Minister of Law and Human Rights can register a business license using the Online Single Submission (OSS) system (Karo Sitepu, 2020:3). Since 2018 the Government has issued Government Regulation Number 24 of 2018 concerning Electronically Integrated Business Licensing Services (PP Number 24 of 2018). PP Number 24 of 2018 states that company registration, both individual and nonindividual, must be carried out through the OSS system. So, since the implementation of the electronic integrated business licensing system mentioned above, business actors do not need to manually manage company lists or other business licenses, but must be done online through the OSS system. Every business actor who carries out his business activities within the territory of the Unitary State of the Republic of Indonesia is required to apply for licensing and non-licensing through the OSS system (Indra Jaya \& Sudantra, 2020: 499).

After the issuance of PP Number 24 of 2018, there were significant changes related to the company's licensing mechanism. According to Government Regulation Number 24 of 2018, now the list of companies must be carried out first before applying for business permits and commercial or operational permits. Owning a Business Identification Number (NIB) is a requirement for obtaining a business license and a commercial / operational license. This can be found in the provisions of Article 25 paragraph (1) of Government Regulation Number 24 of 2018, which states "NIB as referred to in Article 24 is a business identity and is used by Business Actors to obtain Business Permits and Commercial or Operational Licenses including for fulfilling the requirements for Business Permits. and Commercial or Operational License ". Therefore, from the information described in the article, it is very clear that in order to obtain business permits and company operational permits, companies must first have an NIB, which is obtained by registering on the OSS system.

After the enactment of Government Regulation Number 24 of 2018, as stipulated in Article 81, PT, if it carries out its activities, is required to have an NIB. But unfortunately the word "mandatory" here is not followed by a regulation on the existence of "sanctions" if the PT operates without having an NIB (empty norm).

Permit adjustments related to the operational legality of a PT that was established before the enactment of PP 24 of 2018 and does not have an NIB, but already has a SIUP, then legally the company can still operate as usual legally (but not perfect). However, 
companies in this condition are urged to immediately register companies through the OSS system in accordance with the provisions of Government Regulation Number 24 of 2018. This is based on the reason that when viewed from the context of operational legality, in carrying out its business activities the company is required to have the three most vital permits. namely NPWP as taxpayer identity, SIUP as business license, and NIB as official company identity. If the three operational legality are fulfilled, then the company can operate legally in the territory of the Republic of Indonesia (Indra Jaya \& Sudantra, 2020: 501).

Although it is not an absolute obligation for each company to make licensing adjustments, the ownership of NIB as TDP plays a significant role in smoothing the company's business activities. The thing that becomes a problem is if during field inspections, both routine inspections and unannounced inspections, it is found that the company is operating without having an NIB. However, it seems that even this is not considered a big problem considering that the sanctions given are only asked to immediately adjust the management and complete company data. Sooner or later, each PT must adjust its Articles of Association or the purposes and objectives of its business activities and data in AHU online to be able to access OSS to obtain NIB, so that it is not constrained in its business activities because the old business license has expired. This is a form of problem, where there is inconsistency between the law in books in the form of regulatory provisions requiring companies to make adjustments to company licenses according to a predetermined period of time, with law in action where actualization in the field shows a reality that does not comply with the provisions desired by legislation.

Based on the explanation based on the provisions of the laws and regulations above, of course there are consequences for companies (especially those in the form of PT) that do not / do not have NIB as TDP. Even though the company is able to carry out its business activities without having an NIB, of course the process of carrying out the company's business activities will not run freely, because there is no right / access to receive facilities owned by companies that already have NIB as TDP, API, SIUP and not fulfilling the requirements for obtaining a company business license (operational / commercial license). The impact of the PT that does not make adjustments is the same as the non-existence of the PT, even though the PT is not dissolved.

\section{RESEARCH METHODS}

The research used is normative legal research where normative legal research is research conducted by examining library materials or library law research (Ediwarman, 2016: 21). While the approach method applied in this legal research is the statutory approach (Statute Approach) and the approach to the level of vertical and horizontal synchronization. The statutory approach is used because what will be studied are various legal rules that become the focus as well as the central theme of a study (Soekanto \& Mamudji, 2015: 17-19). While the approach to the level of vertical and horizontal synchronization is used to determine the extent to which the written positive law is compatible.

The nature of this research is descriptive analytical which is a study to describe and analyze the problem under study through the data that has been collected as well as by analyzing and making conclusions. While the data sources in this study were obtained from secondary data and supported by primary data. Primary data sources (field research) are data obtained directly from the community who will be researched or research in the field (Salim \& Nurbani, 2016: 15). The primary data sources in this study came from informants from several notaries as well as business actors who owned PT X and primary data sources were only as supporting data. Secondary data is data obtained from literature studies, 
journals and books (Soekanto \& Mamudji, 2015: 13). The technique used to collect data in this study was carried out by document study and interviews, using qualitative analysis.

\section{RESULTS AND DISCUSSION}

Ownership of an NIB is a requirement for obtaining a business license and commercial / operational license. This can be found in the provisions of Article 25 paragraph (1) of Government Regulation Number 24 of 2018 which states that the NIB as referred to in Article 24 is a business identity and is used by Business Actors to obtain Business Permits and Commercial or Operational Permits including to fulfill the requirements for Business Permits and Permits. Commercial or Operational. So from the information described in the article, it is very clear that in order to obtain business permits and company operational permits, companies must first have an NIB, which is obtained by registering on the OSS system.

Ownership of company legality is an embodiment / realization of the principle of legality in a business context, which emphasizes the company's compliance with the laws and regulations governing business activities. With the existence of NIB ownership as an official corporate identity, legal ownership for the company for the company is a manifestation of the company's commitment to realizing legal certainty in carrying out business activities, as citizens with integrity (Indra Jaya \& Sudantra, 2020: 500).

With regard to business certainty, Article 1 number 8 PP 24/18 states that new business licenses and commercial or operational permits can be obtained when the company has registered (already has an NIB). Thus, if the company does not have an NIB as a consequence of not making adjustments to company permits, then of course the company will have difficulty obtaining business permits and commercial or operational permits. This will affect the certainty of doing business by the company, if it is related to the legality of the business. Although it is not an absolute obligation for each company to make company adjustments, the ownership of NIB as TDP plays a significant role in smoothing the company's business activities. It should be remembered that in order to carry out its profitoriented business activities, a company certainly needs legality. Legality in the context of business activities plays a very important role and very significant urgency. In general, legality guarantees the company for the sustainability of its business activities (Fitriani, 2017: 136-145). The urgency of having legality in a PT company includes:

1. Provide legal certainty in doing business, legal certainty emphasizes concrete regulations (laws and regulations) and law-based governance (in this context, laws and regulations). This is closely related to the principle of legality adopted by Indonesia as a state of law (Mulksan, 2017: 6). In the context of the legality of company operations, the legality principle emphasizes the conduct of business activities by individuals and business entities based on law. The principle of legality in this context, including ownership of business permits and operational permits, proves the legitimacy of conducting business activities in accordance with the provisions stipulated by law. With regard to company legality, the legality of a PT business provides legal certainty for the company to carry out its business activities based on the applicable positive legal provisions (in this case the PT Law and other relevant laws and regulations), through ownership of a business license which includes an IMB, SITU, SIUP, TDP, NIB, and others. If a company already has legality, of course this reflects that the legitimacy of the company has been officially recognized by the government, in addition to real business activities carried out by the PT in the trade and / or service business sector. The legality of the PT also provides the validity that the aims, objectives and business activities of the company 
do not contradict the provisions contained in statutory regulations, public order, and morality (Sinaga, 2018: 19).

2. Providing rights and obligations in legal traffic, with the ownership of the company's institutional legality (in this context the legalization of the status of a PT as a legal entity), giving PT legal rights and obligations according to its position as a legal subject. Thus, the PT has the ability to carry out legal actions as long as it does not conflict with statutory regulations, morals, or public interest. Examples include making agreements with third parties, filing suit in court if there is a dispute, and others. Ratification of the status of a PT as a legal entity also relates to the competence of which court has the authority to examine, hear and decide when a dispute occurs.

Article 104 PP Number 24 of 2018 states that business actors who have obtained business permits and / or commercial or operational permits before this government regulation come into effect and require new business licenses and / or commercial or operational permits for business development must follow the provisions as following:

1. submission and issuance of business licenses for business development and / or activities or commercial or operational activities carried out through the OSS system by completing data, commitments, and / or fulfillment of commitments in accordance with the provisions of this government regulation;

2. business licenses and / or commercial or operational licenses that have been obtained and are still valid according to the line of business and / or activities are still valid and registered to the OSS system;

3. business actors are given NIB in accordance with the provisions of this government regulation.

Based on the article above, it can be interpreted that if a business actor has a business license, for example, retail trading of various kinds of goods, mainly food, beverages, or tobacco not in supermarkets / minimarkets (traditional) with a valid SIUP license and does not carry out business development the business does not require registering a license at the OSS to obtain an NIB. However, if a business actor develops a business, for example adding a liquor sales business that requires an Alcoholic Drink Trade Business License (SIUPMB), then the new business license must be carried out through the OSS system. With a note that the said line of business is already contained in the purposes and objectives stated in the company's deed of incorporation.

Apart from business development, in practice, the need for NIB may become something urgent. For example, when a company plans to expand in the form of export and import of goods. As stipulated in Article 26 letter b and letter c PP Number 24 Year 2108 that NIB also applies as Importer Identity Number (API) and customs access rights. Based on Article 2 paragraph (1) and paragraph (2) Regulation of the Minister of Finance Number 71 / PMK.04 / 2018 concerning Electronically Integrated Business Licensing Services in Customs, Excise and Taxation, it is stated that to carry out export and / or import activities business must register customs with the Directorate General of Customs and Excise in order to gain customs access. In the customs registration process, business actors must have an NIB.

PT in entering into an agreement with a third party which in this case is a "bank" is based on a contractual relationship. Legal or contractual relationships in the banking sector, can be in the form of customers placing their funds or customers receiving credit facilities tied up in the form of a bank credit agreement. The parties that commit themselves to the placement of funds and credit agreements are the customer or debtor and the bank. In the fund placement agreement and bank credit agreement, it is stated that the 
parties involved in this legal relationship have their positions adjusted to the transactions carried out at the bank. The bank as a financial institution when it enters into a placement agreement relationship, the bank acts as a borrower. The party that binds itself with the bank is called the customer, whereas if the bank provides credit to a third party it is called a debtor.

The director has the right and authority to represent and bind the company where and in any matter, both inside and outside the court or other judicial bodies, and has the right to carry out for and on behalf of the company all acts of ownership (daden van eigendom) and all acts of management (van beheer curd), thus:

1. To borrow or lend money on behalf of the company (excluding taking company money that is kept in the bank);

2. To acquire and release permanent (immovable) assets, including corporate companies;

3. To pawn or insure in other ways the company's assets;

4. To bind the company as guarantor of debt (borg or availist);

5. To take action in connection with the payment of taxes that must be paid by the company.

Licensing required in the event that a PT becomes a customer or debtor at a bank, is generally required to complete with:

1. Articles of Association / Deed of Establishment

Articles of association or amendments to articles of association made before a notary as a general official who makes the deed of establishment of a PT, registration through the SABH of the Directorate General of General Legal Administration;

2. Company Licensing, which consists of PT NIB from OSS, and PT Business License, as well as PT operational permit through OSS;

3. PT Taxpayer Identification Number (NPWP);

4. Identity Card and NPWP of management in accordance with the deed of establishment / amendment to the articles of association of PT;

5. Value Added Tax (PPN) report of limited liability companies for the last 3 (three) months;

6. Annual Income Tax Return (SPT) for the current year PT;

7. Identity Card (KTP) and NPWP, Family Card (KK), and photo size $3 \mathrm{~cm} \mathrm{x} 4 \mathrm{~cm}$. Management of limited partnership companies or those applying for credit;

8. The original work contract or if it does not yet exist, a Goods / Services Provider Appointment (SPPBJ) or a Work Notification Letter (SPMK) can be attached, if the work is in the form of procurement of goods, then the form is a goods order letter.

Services provided by the bank to PT is one form of public service. The development of technological advances in the current industrial revolution era, also influences the development and progress in the field of public services, the goal is to be able to improve and optimize effectively and efficiently in providing services to the community, especially business actors to support the business activities they carry out.

In addition to the need for API and customs access, also see whether the Deed of Establishment of the Indonesian Standard Business Classification Company (KBLI) is used according to the latest regulations or not. Currently, the KBLI being used is the 2020 KBLI based on the Regulation of the Head of the Central Statistics Agency Number 2 of 2020 concerning the Classification of Indonesian Business Field Standards. Since it was only promulgated in 2020, companies that made a Deed of Establishment before that year have a different KBLI code. 
The PT must be approved by the Minister of Law and Human Rights in relation to the OSS system. This means that OSS is a licensing system that is linked to the aims and objectives of PT. The PT is obliged to have directions on where to carry out its business activities from the aims and objectives, this purpose and objective must be the same as the OSS system, meaning that if it is not suitable then the business group will not run. When the aims and objectives are not in accordance with the $2020 \mathrm{KBLI}$, this PT cannot be endorsed and therefore must be adjusted. The adjustments in the Company's Deed of Establishment that must be made are still mandatory through amendments to the company's articles of association as referred to in the provisions of Article 21 paragraph (2) of the Company Law, where changes in the aims and objectives are amendments to the articles of association which must be approved by the Minister of Law and Human Rights who is the authority Notary Public.

The Company's Deed of Establishment must state the aims and objectives that must be filled in according to the 2020 KBLI. Inclusion of the purpose and objectives and business activities of the PT in the Articles of Association holds a principal function, because its inclusion is the legal basis for PT management, namely the board of directors to carry out the management of PT. by including the purpose and objectives as well as the business activities of the PT, the management of the PT cannot carry out transactions beyond the said aims and objectives and business activities. If the purposes and objectives in the Company Establishment Deed are not in accordance with the 2020 KBLI or filled with the KBLI before 2020, then it must be adjusted within 1 year as stipulated in the Joint Announcement letter of the Ministry of Law and Human Rights of the Republic of Indonesia cq. Directorate General of General Legal Administration and the Coordinating Ministry for Economic Affairs of the Republic of Indonesia cq. OSS Institution (Joint Announcement). However, if the company does not need an NIB in the near future, the government will provide a period of time for businesses to upgrade through the OSS system.

As for the legal consequences of companies that already have business licenses such as SIUP but do not plan to update their licenses through the OSS system, no sanctions are found to be applied to these business actors. However, it is possible that a business actor will not enjoy the convenience of doing business like a business actor who has an NIB. Moreover, there is information that for opening a bank account in the name of a company, there is a new requirement where an NIB is required. In other words, if a company needs business development, ownership of NIB is a necessity (Hukum Online, 2020).

Lon Fuller's opinion above can be said that there must be certainty between regulations and their implementation, thus entering the realm of action, behavior, and the factors that influence how positive law is carried out. According to Fuller, there must be compliance with regulations and daily implementation, adjustment of PT permits after the enactment of PP Number 24 of 2018, namely the existence of an identity of a business actor called NIB as well as an endorsement of Company Registration (TDP) in the context of implementing business activities and is valid for running business activities according to the provisions of laws and regulations, issued by the OSS institution and its business activities according to the 2017 KBLI through the SABH (System of Administration of Legal Entities) of the directorate general of general law administration. Such adjustments are made through amendments to the company's articles of association as referred to in the provisions of Article 21 paragraph (2) of the Company Law which must be approved by the Minister.

It is seen and understood that PP Number 24 of 2018 has many weaknesses, one of which is the absence of regulations that regulate the legal consequences that occur if a legal entity has been established before PP Number 24 of 2018. The Law No. there is no 
sanction that can be imposed on a PT that was established prior to the enactment of the UUPT that does not make licensing adjustments to the Company Law. However, there are also no clear regulations for business actors who are required to adjust business permits through online after the enactment of Government Regulation Number 24 of 2018. It's just that if there is neglect or neglect of business adjustments towards business licensing, NIB will not reach the stage of PT dissolution but will have an impact Temporary suspension (freezing) or revocation of business licenses is contained in Article 81 PP Number 24 of 2018. Based on this provision, a PT if it carries out its activities is required to have an NIB. But unfortunately the word "obligatory" here is not followed by a regulation on the existence of "sanctions" if the PT operates without having an NIB, which means an empty norm.

Although it is not an absolute obligation for each company to make licensing adjustments, the ownership of NIB as TDP plays a significant role in smoothing the company's business activities. The thing that becomes a problem is if during field inspections, both routine inspections and unannounced inspections (sidak), it is found that the company is operating without having an NIB. However, it seems that even this is not considered a big problem considering that the sanctions given are only asked to immediately adjust the management and complete company data. It's just that business actors will suffer losses if they do not make adjustments in the sense that they cannot cooperate with third parties.

Gustav Radbruch stated 4 (four) basic things related to the meaning of legal certainty, namely:

1) that law is positive, meaning that positive law is legislation.

2) that the law is based on facts, that is, it is based on reality.

3 ) that facts must be formulated in a clear manner so as to avoid confusion in meaning, as well as being easy to implement.

4) positive law cannot be easily changed (Sidharta, 2008: 20).

Gustav Radbruch's opinion is based on his view that legal certainty is certainty about the law itself. So according to Gustav Radbruch, positive law that regulates human interests in society must always be obeyed even though positive law is not fair. Sooner or later, each PT must adjust Article 3 of its Articles of Association, namely where the aims and objectives of its business activities are in accordance with the $2020 \mathrm{KBLI}$ at the Directorate General of AHU and integrated by OSS to obtain NIB, so that it is not constrained in its business activities because the old business license has expired (expired). Even though the articles of association contain details of the activities, if the activities mentioned in the articles of association do not have any activities, basically the company is deemed to no longer exist as a legal entity. In such circumstances, it is better for the PT to be "dissolved" based on the GMS by the shareholders based on Article 142 paragraph (1) letter a jo. Article 142 paragraph (3) Company Law and based on a Court decision in accordance with the provisions of Article 142 paragraph (1) letter c jo. Article 146 Company Law.

According to Sudikno Mertokusumo, the function of legal protection is that the function of law and legal protection, as protection of human interests, has a purpose. The law has a goal to be achieved. The main principle of law is to create an orderly social order, to create order and balance. By achieving order in society, it is hoped that human interests can be protected. In achieving its objectives, the law is tasked with dividing rights and obligations between individuals in society, dividing authority and regulating how to solve legal problems and maintaining legal certainty (Mertokusumo, 1987: 2). 
Notaries also have the obligation to convey the application of OSS to business actors. Notaries themselves will not be subject to any sanctions if they do not remind business actors about the existence of this OSS system. The notary in this case is only responsible for the preparation of the Notary Deed related to the adjustment of Article 3 of the Purpose and Objectives as requested by the Business Actor. With the provision of a 1 year OSS time limit, there has been no clear sanction if a business actor later exceeds the 1 year time limit.

Thus, to provide legal protection for business actors, they must make adjustments by making amendments to the Articles of Association and obtaining approval for the approval of the Minister of Law and Human Rights by changing the aims and objectives according to Article 21 of the Company Law, if not legalized then this PT cannot move and will not be accepted by third partie. Legislations are still weak and do not regulate legal protection for business actors to match the PT which was established first. These intentions and objectives have been documented on the part of the Ministry, where the data is directly integrated by OSS. However, the impact of the PT does not adjust its business activities according to KBLI 2020, so it is the same as not living the PT even though it is not dissolved.

\section{CONCLUSION}

Legal protection of limited liability companies that do not make business licensing adjustments through online single submissions after the issuance of PP Number 24 of 2018 concerning electronic integrated business licensing services, namely weak laws and regulations that do not regulate legal protection for business actors who do not make adjustments, because they are still Weakness PP Number 24 Year 2018. In the amendment to the Articles of Association, if it is not approved by the Minister of PT, this will not move and will not be accepted by third parties. However, the impact on the PT does not make adjustments, so it is the same as the non-existence of the PT even though it is not dissolved.

For this reason, in order to provide legal protection for business actors, it is necessary to revise existing laws and regulations because the current regulations are still very weak and do not regulate protection for business actors.

\section{REFERENCES}

Ediwarman. (2016). Monograf Metodologi Penelitian Hukum (Panduan Penulisan Skripsi, Tesis Dan Disertasi), Cet. 3, Yogyakarta: Genta Publishing, 2016.

Fitriani, Rini., (2017). Aspek Hukum Legalitas Perusahaan Atau Badan Usaha Dalam Kegiatan Bisnis. Jurnal Hukum Samudra Keadilan, 12(1), 136-145.

Harahap, M. Yahya. (2011). Hukum Perseroan Terbatas, Jakarta: Sinar Grafika.

Hukum Online. (2020). Konsekuensi Apabila Perusahaan Belum Memiliki Nomor Induk Berusaha”. Https://Www.Hukumonline.Com/Klinik/Detail/Ulasan/Lt5c0642171e7fc/KonsekuensiApabila-Perusahaan-Belum-Memiliki-Nomor-Induk-Berusaha/, Accesed on $28^{\text {th }}$ September 2020.

HS, Salim., Septiana, Nurbani Erlies. (2016). Penerapan Teori Hukum Pada Penelitian Tesis Dan Disertasi, Jakarta: Rajawali Pers.

Indra Jaya, Dewa Gede., Sudantra, I Ketut. (2020). Legalitas Kegiatan Usaha Perseroan Terbatas Yang Tidak Memiliki Tanda Daftar Perusahaan. Jurnal Kertha Semaya, 8(4), 494.

Karo Sitepu, Minarni Snorita. (2020). Peran Notaris Terhadap Perekaman Akta Perseroan Terbatas (PT) Pada Proses Online Single Submission (OSS)" https://mkn.usu.ac.id/images/16, Accesed on $10^{\text {th }}$ June 2020, p. 3. 
Mertokusumo, Sudikno. (1987). Perlindungan Hukum Bagi Rakyat Indonesia, Surabaya: PT. Bina Ilmu.

Mulksan, M. (2017). Asas Legalitas Dalam Hukum Pidana: Studi Kompatif Asas Legalitas Hukum Pidana Indonesia Dan Hukum Pidana Islam (Jinayah). Serambi Hukum, 11(1), 6.

Sidharta, Arief. (2008). Meuwissen Tentang Pengembanan Hukum, Ilmu Hukum, Teori Hukum Dan Filsafat Hukum, Bandung: PT Refika Aditama.

Sinaga, N.A. (2018). Hal-Hal Pokok Pendirian Perseroan Terbatas Di Indonesia. Jurnal Ilmiah Hukum Dirgantara, 8(2), 19.

Soekanto, Soerjono., \&Mamudji, Sri. (2015). Penelitian Hukum Normatif Suatu Tinjauan Singkat, Jakarta: PT RajaGrafindo Persada.

Zuriah. (2005). Metodologi Penilitian Sosial Dan Pendidikan, Jakarta: Bumi Aksara. 